\title{
DA FORMULAÇÃO DOS CONCEITOS AOS REFORÇOS DOS PRECONCEITOS
}

\author{
Sebastião Rodrigues Gonçalves ${ }^{1}$
}

\begin{abstract}
Resumo:
Este artigo visa analisar, entre tantos outros conceitos, os de superioridade e inferioridade relativos aos processos de legitimação da subordinação entre os nativos e os europeus, desde um processo histórico latino-americano. Para tanto, o ensaio aqui examina o caráter ideológico, portanto, liberal burguês de expropriação do capital e sua lógica perversa, que, em certos momentos, também assume o valor de crença religiosa. É tendo em vista esse quadro que a ideologia da superioridade encontrou, por exemplo, no aparato bélico, estratégias militares dos colonizadores espanhóis, portugueses, ingleses e franceses, reforçando, na consciência dos povos nativos e africanos, esse conceito hegemônico, expressão, portanto, de uma "verdade" universal. A formulação desse conceito é perceptível ainda nos dias atuais (2018) na política, na educação, nas escolas, na universidade e nas relações de trabalho. Esse ponto de vista se apresenta como uma concepção de mundo e permanece petrificada na consciência, inclusive na das vítimas dessa concepção. A superação dessa concepção poderá começar quando este sistema econômico for superado, numa relação dialética entre a produção da existência humana, bem como na relação com as novas políticas econômicas e com a formulação de novas relações socioculturais que superem a concepção imperativa da subserviência.
\end{abstract}

Palavras-chave:Modo de produção; Política econômica; Relações sociais; Produção cultural.

\section{FROM THE FORMULATION OF CONCEPTS TO THE STRENGTHS OF PRECONCEPTIONS}

\begin{abstract}
:
This article aims to analyze, among many other concepts, those of superiority and inferiority related to the processes of legitimation of the subordination between natives and Europeans, from a Latin American historical process. To this end, the essay here examines the ideological, therefore, bourgeois-liberal character of expropriation of capital and its perverse logic which, at times, also assumes the value of religious belief. It is in view of this picture that the ideology of superiority found, for example, in the war apparatus military strategies of the Spanish, Portuguese, English and French colonizers reinforcing in the consciousness of native and African peoples as a hegemonic concept the expression of a universal "truth". The formulation of this concept is still noticeable today (2018) in politics, education, schools, university and labor relations. This point of view presents itself as a conception of the world and remains petrified in consciousness, including the victims of that conception. The overcoming of this conception may begin when this economic system is overcome, in a dialectical relationship between the production of human existence, as well as in relation to the new economic policies and the formulation of new socio-cultural relations that surpasses the imperative conception of subservience.
\end{abstract}

Keywords:Mode of production; Economic politics; Social relationships; Cultural production.

\footnotetext{
${ }^{1}$ Professor de Filosofia da UNIOESTE - Campus de Foz do Iguaçu. Mestre em Educação, Ciência, Tecnologia e Suas Culturas pela UFPR - Universidade Federal do Paraná; Doutor em Políticas Públicas e Formação Humana pela UERJ - Universidade do Estado do Rio de Janeiro. E-mail: srgbelem@gmail.com.
} 
Introdução: poder e dominação

A formação dos Estados nacionais no continente americano, principalmente os Estados do sul da América, transcorreu como uma das maiores tragédias já vistas na humanidade. A chegada dos europeus ao continente foi o impulso que a burguesia precisava para construir o alicerce do novo modo de produção. As descobertas das riquezas que aqui existiam serviu para a burguesia emergente ganhar terreno fora da Europa, vindo, pois, a expandir o comércio com novos produtos.Para os nativos, as riquezas naturais que aqui existiam não tinham nem um significado econômico. Assim, os espanhóis e os portugueses estabeleceram uma relação de dominação sobre os nativos, inclusive visando escravizá-los pela extração de produtos naturais.

Nas relações entre nativos e europeus pode se considerar que havia dois estados de ignorância: do lado europeu, a ignorância sobre os nativos; do lado dos nativos, a ignorância sobre os europeus. Os europeus ficaram perplexos pelos povos que encontraram neste continente, pois ignoravam a cultura, a geografia e tudo o que pôde ser encontrado neste território; da mesma forma, os nativos ficavam admirados pelas quinquilharias trazidas da Europa. Mesmo com uma indústria ainda muito incipiente, o fato de os europeus encontrarem populações americanas ainda sem esses mínimos valores, isso lhes deu o direito de conceituá-los e classificá-los como inferiores, mesmo sem o conhecimento das riquezas materiais e do arsenal cultural que estava para ser descoberto nessesnovos territórios. Por outro lado, os nativos também ignoravam o que vinha do outro lado do Atlântico. Isso acabou contribuindo para que parte desses nativos se alinhasse com a cultura europeia, colaborando, portanto, para a exploração das riquezas e,assim,legitimando a subordinação e o conceito de superioridade e inferioridade.

Parte significativa da população vivia numa relação de harmonia com a natureza, com a selva, com os rios, com as montanhas. Para os povos europeus, a vida na cidade significava desenvolvimento e civilização. Ao contrário dos povos que ainda dependem da extrair produtos naturais para viver, esses, por sua vez, segundo os europeus, eram considerados bárbaros e selvagens, portanto, inferiores aos povos vindos da Europa. Quanto à dominação para fins de extração, apenas no início foi pacífica, pois, quando se tentou escravizar tais povos, deu-se, enfim, origem aos conflitos, aos massacres e aos extermínios.

\begin{tabular}{|l|l|l|l|l|}
\hline Q Rovista Dialectus & Ano 5 & n.13 & Agosto - Dezembro 2018 & p. 78-99 \\
\hline
\end{tabular}


Sabe-se, ainda, que a tentativa fracassada da escravização sobre os nativos foi o ponto de partida para a importação e comercialização de negros africanos,visando, é claro, a extração das riquezas naturais num primeiro momento e à produção agrícola no segundo. Dessa forma, a espada e o fuzil serviram de instrumentos de dominação no sentido mesmo de afirmação dosconceitos de superioridade e de inferioridade. Se os nativos tivessem noção do conceito de riquezas naturais como instrumentos de dominação, seriam eles que dominariam aqueles que aqui chegaram. Ora, o "se" não tem validade para a história e para a pesquisa, mas somente os fatos reais são considerados para a interpretação da realidade política, econômica e social.

Cabe observar que, para os nativos, era um absurdo o conceito de propriedade privada da terra, por exemplo. Menos ainda dos minérios aqui encontrados, como ouro, cobre, prata, ferro, dentre outros. Dessa maneira, foi reafirmado o conceito de civilização, conforme também os valores econômicos vigentes, a fim de contrastar com o de barbárie ou de selvageria.Na lógica formal clássica relativa ao verbo "Ser", tudo o que se apresenta de tal modo como uma realidade absoluta, seja nosubstantivo dos objetos materiais, ou nas relações sociais, vem acompanhado de um reforço valorativo puramente conceitual. Ora, assim como Parmênides dizia que o que éé e não pode ser diferente, também os conceitos de superioridade e de inferioridade se transformam em preconceitos, reforçando a discriminação entre povos e a população que não se apega ao capital como instrumento de defesa e de dominação. Dessa forma, a dominação e o extermínio se apresentam como situações irrefutáveis para quem os exerce. Ou é aceito o enquadramento na lógica produtivista ou o grupo nativo é exterminado. Há que produzir, mas a produtividade não lhe pertence. Essa é a lógica das relações de dominação, exploração e expropriação dos produtos do trabalho pelos agentes hegemônicosdo capital.

Quais foram os instrumentos (científicos) que os europeus trouxeram para dominar este continente? A bíblia na mão esquerda, o fuzil e a espada na mão direita! Com o evangelho, eles ensaiaram um discurso da submissão ao Ser superior, o qual eles representavam, para então dar início ao processo de escravização aos nativos. Quando a evangelização era insuficiente, o fuzil e a espada reforçavam o massacre. Em síntese, ocorriam dois massacres por assim dizer: o primeiro, de aculturamento, sedução, indução ao processo de adesão a uma ideologia da submissão ao domínio europeu; quando esse processo era ineficaz, então se apelava para acoerção e o massacre

\begin{tabular}{|l|l|l|l|l|}
\hline Q Rovista Dialectus & Ano 5 & n.13 & Agosto - Dezembro 2018 & p. 78-99 \\
\hline
\end{tabular}


físico. Assim foi acontecendo o processo de trabalho forçado nas minas a partir do século XVII. Foi essametodologia (científica) que legitimou os preconceitos da superioridade europeia e da inferioridade aos nativos, aborígenes. Com isso se afirmou, nas relações sociais, o conceito de inferioridade e de superioridade, transformando-se em preconceito e produzindo discriminação aos desprotegidos da leivia os próprios dominadores.

A formação dos Estados nacionais na América Latina aconteceu em função da necessidade da organização do capitalismo mundial. Ora, no período colonial, o poder econômico havia se concentrado nas metrópoles. As colônias seguiam as leis metropolitanas. Já os nativos, praticamente mal sabiam da existência das leis, mas que, por força ideológica, eram aplicadas severamente a eles. Desse modo, as forças das armas foram determinantes nas relações entre esses dois povos. O domínio das águas, das florestas, dos recursos aos improvisos de armamentos rústicos eram possibilidades de resistência e muitas vezes vitória para os nativos. Quanto, porém, às riquezas naturais, os nativos não consideravam como valor de mercado; na verdade, o que eles não desejavam era serem explorados e massacrados fisicamente para extração dessas riquezas. Com a organização dos Estados nacionais se estruturaram também as forças armadas,consolidando-se, pois, o domínio da cultura eurocêntrica sobre os nativos e sobre negros de origem africana.

O poder bélicofez parte e continua como estrutura de dominação nos Estados nacionais. A questão é que o reportadoconceito de superioridadesegue presente na consciência de muitas cabeças eurocêntricas como algo natural, biológico ou divino. Do outro lado da moeda, se os nativos não tivessem um poder de organização, força e criatividade não sobraria um para contar a história a fim de assegurar a cultura da resistência. Então, o que é a consciência deste povo latino? Pode-se dizer que é a síntese da contradição entre o genocídio imputado aos povos nativos, o comércio de escravos e massacre sobre os negros africanos como resistência em quilombos e outras formas de organizações. Onde está a verdade? Na síntese dessas contradições. Aprofundemos mais esse ponto.

Nas relações sociais entre os povos europeus, incluindo os missionários católicos que tinham como finalidade impor a doutrina cristã aos nativos, se forjou o conceito de inferioridade entre os povos nativos tidos, quando resistiam, como heréticos. A heresia, por exemplo, se torna também uma noção hegemônica na Igreja

\begin{tabular}{|l|l|l|l|l|}
\hline Q Rovista Dialectus & Ano 5 & n.13 & Agosto - Dezembro 2018 & p. 78-99 \\
\hline
\end{tabular}


Católica, especialmente no período da Inquisição (1478-1750). O que cabe notar é que se, de um lado, na América Latina, há a influência da colonização católica, de outro, na América do Norte, não houve propriamente processo colonizatório, mesmo que a cultura protestante fosse a mais influente. Esse dado ajuda a compreender a disparidade em termos de caracterização cultural entre ambos. Ora, a chegada dos europeus na América, exatamente na época em que a Inquisição estava operando com todas as forças na Europa, refletiu diretamente no relacionamento com os povos nativos, no caso, aqui, é claro, latino-americanos. Daí resulta uma "maldita" herança: aedificação das estruturas do poder político, as escolas e educação sofreram e sofrem influência dessas relações de poder até o presente momento.

Essa é a concepção de mundo que predomina nas relações sociais hoje, em nosso continente. O próprio sujeito que é massacrado tem em si o conceitode inferioridade, como obra do destino e até de castigo divino. Isso está petrificado na consciência popular, principalmente porque recebe influência da mídia e diuturnamente de pastores, charlatões eclesiais que agenciam seus discursos em meio a um mercado altamente atrativo (lucrativo) para vender a ilusão da vida eterna. As igrejas pentecostaisse valem da pobreza e da miséria da populaçãoa fim de vender a ilusão de que o sofrimento aqui proporciona a vida eterna. Assim, quanto mais desinformado um povo, tanto maior o número de vítimas desses mercadores do espaço celestial. Grande parte da população acaba perdendo de vista as contradições inerentes a essa lógica encampada por aqueles que pregam o sofrimento aqui e agora,vendendo-lhe ideologicamente um paraíso para depois.

Em tal direção, pode-se concluir que a superação dessa concepção de mundo (onde os conceitos a priori se transformam em conceitosdefinitivos, petrificando-se na consciência popular como verdade) só se torna possível provocando uma reviravolta no modo de produção hegemônico do capital. Para que isso aconteça, é necessário retomar o conceito de igualdade, para imprimi-lo nas bandeiras de lutas. As lutas pela igualdade social deverão ser uma bandeira que caminha organicamente, numa relação dialética com as lutas pela igualdade econômica. Este é o horizonte que a esquerda mundial persegue.

Dessa forma, o povo da América Latina, assim como a população africana, não devem sentir-se menores, inferiores aos povos do continente europeu. Este é um continente ainda com as maiores reservas de riquezas naturais, com intelectuais

\begin{tabular}{|l|l|l|l|l|}
\hline Q Rovista Dialectus & Ano 5 & n.13 & Agosto - Dezembro 2018 & p. 78-99 \\
\hline
\end{tabular}


comprometidos com a defesa de um mundo justo. É, portanto, inadmissível o contraste social neste continente. Torna-se, portanto, necessárioencontrar um caminho através da organização das classes subalternasque protagonize uma luta pela superação da cultura da subserviência. Nesse sentido, a organização de classe é um imperativo se almejarmos superar os princípios da submissão. É inadmissível esse contraste social e econômico, em que tanta miséria coexiste ao lado das maiores riquezas naturais do mundo sugadas pelos poderes do capital com sede nos países imperialistas. Ora, essa mudança exige uma revisão histórica.

\section{Revisão da História na América Latina}

Já vimos que, na formação dos Estados nacionais da América Latina, predominou a cultura da superioridade europeia sobre os nativos. Nessa relação se afirmou o direito dedominação e o conceito de superioridade como expressão da ciência e da verdade. São conceitosque se tornaram sólidos na história, reproduzindo-se sob a forma depreconceitos sobre os povos destituídos de origem europeia. Por exemplo, o nazismo e o fascismo não são apenas ideias vagas. Existem ações práticas que orientam as pessoas que se afirmam por esses conceitos.

Tais fundamentos não se afirmam como categorias universais, mas são apenas categorias teóricas para reforçar e legitimar teorias de subordinação, com a tentativa de legitimar o direito da dominação e de massacre sobre aqueles que são desprovidos de capital. Esse direito emanado dos representantes das metrópoles sobre as colônias nos primeiros momentospassou a ser reproduzido no segundo momento com a formação dos Estados nacionais.

A questão é que, num segundo momento, já com o desenvolvimento do capitalismo industrial, as mudanças aconteceram sobre o interesse do capital, com sede nos países desenvolvidos, com interesses na expansão do mercado mundial. Foi nesse período que aconteceram as duas grandes guerras pelas disputas das riquezas que estão distribuídas no planeta. Ambos os eventos influenciaram na economia, na cultura e na educação da América Latina.

\section{Econômica política e cultura na América Latina}

\begin{tabular}{|l|l|l|l|l|}
\hline Qevista Dialectus & Ano 5 & n.13 & Agosto - Dezembro 2018 & p. 78-99 \\
\hline
\end{tabular}


$\mathrm{O}$ que procuravam os europeus quando chegaram neste continente? Procuravam ampliar o comércio, mas encontraram pessoas que nem sabiam o que significava mercado, comércio e riqueza; não sabiam também da existência de outros povos além das águas oceânicas. Da mesma forma, os europeus também não sabiam que encontrariam pessoas tão diversas, desprovidas de tudo, inclusive dos preconceitos trazidos por elesmesmos de seu continente. Desse modo se constituiu uma relação entre esses dois povos, num primeiro momento, originando, por parte dos europeus,certa concepção de superioridade. Foi com essa ideologia matriz que eles tentaram transformar os nativos em trabalhadores escravos para extrair as riquezas naturais a serem enviadas para as metrópoles.A segunda estratégia se deu com o comércio negreiro e escravização dos povos africanos.Com isso se consolidaainda mais um conceito de superioridade europeia sobre os nativos e os negros. Trata-se de uma superioridade forçadas pelos instrumentos bélicos, mas que foi se reafirmando como costume, cultura e uma concepção da moral dominante.

É assim que, após trezentos anos, as colônias se transformaram em Estados nacionais para atender os interesses do capitalismo que já estava estruturado em pleno curso na Europa. A América Latina se tornou um continente fornecedor de matériaprima, tendo em vista que já havia consumidores necessários, conforme interesses do capital internacional.Nesses primeiros três séculos de ocupação europeia sobre América, o capitalismo ainda não se havia consolidado como sistema universal. Já havia, contudo,indícios pela expansão do comércio, razão que impulsionou a chegada dos europeus ao continente. Como bem observou Marx (2008, p. 13): “A descoberta da América e a circum-navegação da África abriram um novo campo de ação para a burguesia nascente". Tal burguesia visou, sem dúvida, estabelecer relações comerciais ao encontrar um continente com riquezas naturais para explorar, além de um povo avesso completamente aos valores tanto culturais quanto econômicos europeus.

A partir desse momento, oconceito de superioridade se afirmou como verdade na subjetividade humana da população latino-americana. O que a América perdeu, na história moderna, foi o que o capitalismo europeu ganhou; assim se expressa Eduardo Galeano (1984, p. 14): “[...] a história do subdesenvolvimento da América Latina integra, como já disse, a história do desenvolvimento do capitalismo mundial". Embora a superioridade e o domínio se valessem da coerção, via, inclusive, todo o aparato bélico da época, mesmo assim o conceito de superioridade se consolidou através

\begin{tabular}{|l|l|l|l|l|}
\hline Qonista Dialectus & Ano 5 & n.13 & Agosto - Dezembro 2018 & p. 78-99 \\
\hline
\end{tabular}


das leis com a criação dos Estados nacionais a partir do século XIX. A força criou o poder, mas os povos não o legitimaram.

No Brasil, o primeiro a denunciar o massacre sobre índios e escravos foi o padre Antônio Vieira. Por isso, ele sofreu as consequências e também foi perseguido, inclusive pela Inquisição, principalmente porque Portugal estava vivendo sob o domínio da coroa espanhola. Nesse período, Portugal havia perdido o trono para a Espanha no momento em que Vieira havia estado em Lisboa. Foi ele o primeiro a denunciar os massacres sofridos por esses povos, razão pela qual ele mesmo teve que deixar o Brasil.

\footnotetext{
Em 1661, Padre Vieira foi obrigado a deixar o Maranhão, pressionado pelos senhores de escravos que não concordavam com suas posições contrárias à escravidão indígena. Voltou para Lisboa, onde foi condenado pela inquisição em virtude de seus manuscritos heréticos. (Disponível em: $<$ https://educacao.uol.com.br/biografias/antoniovieira.htm?cmpid=copiaecola $>$. Acesso em: 25 jan. 2018).
}

O padre Antônio Vieira é expressão das contradições históricas e da concepção de justiça - o lado humano exigiu que ele denunciasse, o lado religioso o levou à condenação. Naquele episódio entre a vida religiosa e política de Vieira ficou evidente que há uma distância entre a teoria da justiça, a concepção de direito e a aplicabilidade dos conceitos de penalidade ao juízo de quem julga o que é e o que não é crime. Vieira estava numa cruzada entre a teoria do direito natural, a teoria do direito divino e a teoria do direito privado. Como interpretar a justiça entre o cruzamento dessas três teorias? O próprio Antônio Vieira é expressão dessa contradição, quando defende reconhecer o direito de receber de volta os judeus para reforçar o comércio de Portugal. Nessa concepção, estão os fundamentos do direito privado, mas, quando ele defende a não escravidão dos índios e dos negros, estão presentes os direitos humanos. Quando defende o domínio através da catequese, os fundamentos já são outros, os do direito divino.

Na Europa, a Inquisição havia se instalado havia mais de 150 anos: "No dia $1^{\circ}$ de setembro de 1478 , o papa Sisto IV assinou a bula ExigiteSinceraeDevotionisAffectus ${ }^{2}$, através da qual fundou a nova Inquisição na Espanha" (Bethencourt, 2000, p. 17). Vieira pertencia à companhia dos jesuítas e, quando foi para Lisboa,em 1641, seus sermões seduziram a Rainha Cristina. Em função disso, foi nomeado embaixador para negociar com a Holanda a retirada de Pernambuco,

${ }^{2}$ Tradução do Google, em 26 fev. 2018: "Exigir Sincera Devoção".

\begin{tabular}{|l|c|c|c|c|}
\hline Ronita Dialectus & Ano 5 & n.13 & Agosto-Dezembro 2018 & p. $78-99$ \\
\hline
\end{tabular}


porém não obteve sucesso. Voltando para o Brasil, ele se estabeleceu no Maranhão e lá ficou do lado dos índios, lutou contra a escravidão e, por isso, foi expulso pelos senhores de escravos, que tinham o alto clero aseu favor.

\begin{abstract}
De volta ao Brasil, segue para o Maranhão com o objetivo de libertar os índios injustamente cativos. Em 1661, foi expulso do Maranhão, pelos senhores de escravos que não aceitavam suas ideias. Voltou para Lisboa, onde foi preso pela inquisição, que o acusou de heresia. Anistiado em 1669, viajou para Roma, quando foi absolvido pelo Papa em 1675. (Disponível em: <https://www.ebiografia.com/antonio_vieira/>.Acesso em: 26 jan. 2018).
\end{abstract}

Ora, os fundamentos da justiça se expressam como conceitos particulares, não sendo, pois, categorias universais. A justiça, desde a Antiguidade clássica, sempre teve a feição da classe dominante; e, mais do que nunca, na sociedade moderna tem a face do capital. São teorias formuladas pela classe dos possuidores, com objetivo de legitimar o poder político. Disso se deduz que, se o poder político fosse legítimo, não precisaria de forças armadas para proteção dos usurpadores da justiça.Ora, mas o que é a justiça? Qual é o conceito fundamental de justiça? Qual é a relação com o direito? Qual é o conceito fundamental do direito? Revisitemos brevemente isso.

\title{
Justiça: concepção clássica
}

Desde a Grécia antiga, o conceito fundamental da justiça está no direito aos bens necessários para a garantia da vida. Em virtude disso, todo o ser humano carece de alimento, moradia e vestuário. Isso todos os pensadores de bom senso, de Platão a Marx, afirmaram inequivocamente. Ao mesmo tempo, por outra parte, a sociedade burguesa criou outro conceito de necessidade e de justiça. Fato é que, na antiguidade, os gregos se debateram com o problema da justiçana tentativa de encontrar relações justas entre o senhor e o escravo. Em A República, de Platão, o sofista Trasímaco já dizia para Sócrates que "[...] a justiça é a conveniência do mais forte” (PLATÃO, 1991, p. 25). Em seguida, porém, Sócrates refuta os argumentos, tratando do que é necessário para a vida, para que se realize a justiça. Ele mesmo afirma categoricamente que "[...] a primeira e a maior de todas as necessidades é a obtenção de alimentos [...]; a segunda é a habitação; a terceira o vestuário, e coisas do gênero" (PLATÃO, 1991, p. 56). Essas são as premissas básicas para a vida com liberdade. Ao retirar do ser humano os meios para

\begin{tabular}{|c|c|c|c|c|}
\hline Qonista Dialectus & Ano 5 & n.13 & Agosto - Dezembro 2018 & p. $78-99$ \\
\hline
\end{tabular}


obter alimentação, moradia e vestuário, dele também se retiram a liberdade e o direito de viver. Por isso, em Marx, os primeiros passos para a libertação visam também à conquista desses direitos básicos.

Libertação é superação da escravidão, da servidão e da alienação. Isso só será possível, segundo Marx, com o desenvolvimento da ciência e da tecnologia, mas não (observemos bem) como instrumento privado de uma classe. Se a descoberta da América foi um processo do qual a burguesia muito se favoreceu, a Revolução Industrial foi o segundo tempo da extração de valores da própria América. Mesmo os operários europeus não foram contemplados com o desenvolvimento da indústria. Ora, nem por isso os explorados se posicionaram contra tal processo, uma vez que a libertação humana passa também pelo processo da distribuição da ciência e da tecnologia. Eis então a razão, na mesma via lógica de $A$ República,de Platão, que teria levado aconstatar Marx (2007, p. 29):

[...] nem a servidão sem a melhora da agricultura, e que, em geral, não é possível libertar os homens enquanto estes forem incapazes de obter alimentação e bebida, habitação e vestimenta, em qualidade e quantidade adequadas.

O fato é que os nativos que aqui viviam tinham a garantia da alimentação, da moradia e das vestimentas. Com a chegada dos europeus, tais direitos lhes foram negados. O uso ideológico dosconceitosde superioridade e de inferioridade fez com que os europeus tentassem transformar os nativos em escravos.E isso não naquele modelo da antiguidade cujo escravo tinha garantia de alimento, moradia e vestimentas, garantia que existia,mesmo que precária. Na relação entre o senhor e escravo, o conceito de violência também foi tratado como direito do senhor, caso o escravo não cumprisse com seu dever? Isso foi levado ao pé da letra, como se diz na linguagem popular. Isso era legítimo? Se fosse legítimo não precisaria de força física para assegurar o direito de exploração, a fim de que os donos do capital (minoritários) submetam a maioria dos seres humanos ao trabalho para produção e concentração de riquezas.

Afinal, quem está no poder sempre precisa de forças auxiliares como instrumento de dominação política. Essas forças têm poder de persuasão, através da educação; poder de coação, através do poder judiciário; poder de repressão, através das forças armadas. Essa é, em suma, a história da organização dos Estados nacionais no intuito de assegurar o direito de expropriação das riquezas naturais, que deveria ser para

\begin{tabular}{|l|l|l|l|l|}
\hline Q Rovista Dialectus & Ano 5 & n.13 & Agosto - Dezembro 2018 & p. 78-99 \\
\hline
\end{tabular}


o bem-estar da humanidade. Dessa maneira, a classe dominante, por meio dos cartórios, atribuiu para si o direito da propriedade privada.Ora, foi isso que aconteceu na América Latina, foi isso que aconteceu no Brasil.

Não passava pela mentalidade dos nativos que pudesse haver conceitos tais comoeconomia, riqueza, propriedade privada, acumulação de riquezas, exploração, extorsão. O que eles necessitavam para viver estava originariamente na natureza. Eles não valorizavam os minerais porque não se alimentavam do ouro, da prata, do cobre. A produção e a arte estavam relacionadas com a vida. Tinham suas crenças, mas não conheciam uma religião, não conheciam o evangelho, não sabiam o significado de desenvolvimento. Ora, mas qual é o significado de desenvolvimento? Quanto a isso, "O desenvolvimento" - escreve Galeano (1984, p. 15) - "desenvolve a desigualdade". Tratava-se, na verdade, de um processo em pleno curso na Inglaterra da época e denominado de Revolução Industrial.

\section{Revolução Industrial e o Imperialismo Inglês}

O século XIX foi marcado pela Revolução Industrial na Europa e a independência dos países da América Latina. Por isso, como vimos, a formação dos Estados nacionais foi uma necessidade para alavancar o capitalismo mundial.A Revolução Industrial foi o primeiro passo para a consolidação do imperialismo inglês,desencadeando, em função disso, o aumento do massacre dos povos nativos na América. O imperialismo se caracteriza pelo monopólio de algumas empresas, principalmente nos setores estratégicos da economia e o fim do livre mercado. Disso resulta,como escrevera Lenin $(2012$, p. 47), que, “[...] a concorrência transforma-se em monopólio". Assim, várias empresas se unem para evitar a concorrência, fazendo com que o Estado sirva de protetor, contribuindo, inclusive, com a violência sobre aqueles que tentam reagir às formas de exploração e opressão. Foi assim que o capital se estendeu sobre o continente americano.

A riqueza dos países europeus, principalmente os industrializados, não seria possível com a mesma velocidade sem a exploração das riquezas da América. Por isso, Galeano afirmava: que perdemos para outros ganharem; os que ganharam produziram a fome e a miséria deste povo. Daí deriva o medo de que essa população se rebele. Rebeliões aconteceram várias, mas quase todas esmagadas por forças bélicas. " $N a$

\begin{tabular}{|l|l|l|l|l|}
\hline Q Rovista Dialectus & Ano 5 & n.13 & Agosto - Dezembro 2018 & p. 78-99 \\
\hline
\end{tabular}


América Latina é mais higiênico matar os guerrilheiros nos úteros do que nas serras ou nas ruas"'(GALEANO, 1984, p. 18). É a solução que os representantes do capital encontram para evitar que os nativos lutem por outro modo de produção tendo em vista a superação da espoliação.

Através dos cartórios, tais representantes forjaram o direito de propriedade da terra; além disso, produziram o latifúndio, construíram exércitos com caudilhos, que,ao mesmo tempo em que tinham o domínio das terras, detinham também as armas para massacrar a população, caso necessário fosse. Esses caudilhos contavam, também, além das armas, com mestiços que se voltavam contra a população por interesses próprios. Assim se formou a concentração das terras mais produtivas e a população pobre. A maioria ficou sem terra, ou foi para as montanhas e serras; já outra parte foi compor a população de miseráveis das cidades. Qual é a solução que a burguesia internacional propõe? Esterilização, castração e veneno para os pobres. Os países que tentam organização autóctone são massacrados, como foi o caso do Paraguai. A formação dos Estados nacionais foi um processo de interesses do comércio internacional, principalmente com a Inglaterra.

Foi esse processo que forjou a formação dos Estados nacionais na América Latina, processo esse no qual a nobreza do Brasil se prestou a ser subserviente ao imperialismo inglês, contribuindo para frear do desenvolvimento autóctone do Paraguai. Como bem se expressa a respeito Chiavenatto (1979, p. 72): “O império do Brasil era o paladino do que se representa como 'civilização' na época, tão zelosamente divulgado pela Inglaterra". Para manter o controle sobre o mundo, a Inglaterra, tanto promovia guerras como patrocinava países dependentes, como foi o caso da guerra do Brasil com Paraguai em 1860. O que aconteceu? E como ficou o Paraguai com a Guerra patrocinada pela Inglaterra? Segundo Galeano, a guerra da Tríplice Aliança contra o Paraguai aniquilou a única experiência, com êxito, de desenvolvimento independente. Agora:

Somam meio milhão os paraguaios que abandonaram a pátria, definitivamente, nos últimos vinte anos. A miséria empurra os habitantes do país que era, há um século, o mais avançado da América do Sul. O Paraguai tem hoje uma população que apenas duplica a que tinha, naquela época, e é, com a Bolívia, um dos dois países sul-americanos mais pobres e atrasados. Os Paraguaios sofrem a herança de uma guerra de extermínio que se incorporou à história da América Latina como seu capítulo mais infame. Chamou-se a Guerra da Tríplice Aliança. Brasil, Argentina e Uruguai tiveram a seu cargo o genocídio. Não deixaram pedra sobre pedra nem habitantes varões sobre os escombros. Embora a Inglaterra não tenha participado diretamente na horrorosa façanha, foram seus mercadores, seus banqueiros e

\begin{tabular}{|l|l|l|l|l|}
\hline Qovista Dialectus & Ano 5 & n.13 & Agosto - Dezembro 2018 & p.78-99 \\
\hline
\end{tabular}


seus industriais que se beneficiaram com o crime do Paraguai. A invasão foi financiada do começo ao fim, pelo Banco de Londres, a casa BaringBrotheres e banco Rothschild, em empréstimos com juros leoninos que hipotecaram o destino dos países vencedores.(GALEANO, 1984, p. 205).

Dessa guerra resultou o conceito da inferioridade do Paraguai em relação aos países que participaram do massacre. Trata-se de um conceito que, até o presente momento - 2018, mina ideológica e economicamente uma parcela da população paraguaia, que continua sofrendo os efeitos, através de brasileiros que se acham superioresentrando nesse país vizinho, e com isso se apropriando das terras a preços irrisórios, além, é claro, de difundiro mito de que os paraguaios são preguiçosos, não trabalham e, portanto, não merecem terras. Quem atravessa a Ponte da Amizade em Foz do Iguaçu vê crianças maltrapilhas tentando vender alguma coisa para viver. Do lado brasileiro, se veem adultos, homens e mulheres levando a vida, com o conceito de que o Brasil é um país melhor para se viver.

A lógica da concentração de capital e riqueza é a mesma em todos os países regulados pelas leis do mercado. No primeiro momento, na fase do capitalismo comercial, a lógica era da concorrência. Já os cartórios, todavia, foram criados para registrar o direito da propriedade privada da terra, mas não só isso. Inclusive, o casamento que se registra em cartóriochancela um ser humano sob a posse e propriedade privada do outro. Esses são os valores da sociedade burguesa.

\section{Conceitos, teorias e conhecimento científico}

A formulação de conceito não tem condições de se afirmar como teoria do conhecimento, se tomar a ciência como referencial teórico. O conceito flutua na aparência se não penetrar intrinsecamente na essência. Ele se revela, sem dúvida, nos fenômenos, pode ter uma base nos fundamentos da linguagem, via uma estrutura lógicoformal, mas pode também deixar de reconhecer uma dialética materialista, ao produzir ilusão, sedução e persuasão na formação da consciência e da subjetividade humana. Nesse sentido, sua validade é tal e qual ao preconceito. Foi essa aparência que referendou o conceito de inferioridade, reforçando os preconceitos e a discriminação sobre os povos nativos da América e os negros que vieram na condição de escravos da África.Com esses princípios foi reproduzido o conceito de superioridade do homem branco sobre os demais. Assim surgiu o nazismo, surgiu o fascismo reproduzido em

\begin{tabular}{|l|l|l|l|l|}
\hline Qenista Dialectus & Ano 5 & n.13 & Agosto - Dezembro 2018 & p.78-99 \\
\hline
\end{tabular}


certa dose na América Latina. Isso está implícito, em certas medidas, ou até explícito, nas relações pedagógicas, na educação e nos fundamentos da educação escolar. Basta olhar com cuidado certas práticas de professores, de alunos ou de pais de alunos.

\section{Relações Internacionais}

Os europeus chegaram a este continente no ápice da Inquisição, mas a formação dos Estados nacionais já aconteceu sob a égide do liberalismo, para atender às necessidades do mercado internacional, que estava se expandindo, principalmente com a influência da emancipação dos Estados Unidos da América do Norte - EUAvia processos como a Revolução Francesa e a Revolução Industrial. A igreja católica já perdia influência, uma vez que não tinha hegemonia sobre o mundo, perdendo, pois, terreno para o liberalismo, que defendia a liberdade religiosa, mas com objetivo de organizar o capital. Essas premissas orientaram a Revolução Francesa e a constituição de 1792 na França, mas também foi com essa mesma base ideológica que os EUA se tornaram independentes da Inglaterra.

A ocupação da América do Norte sob orientação protestante influenciou na organização republicana dos demais países da América. Para os nativos, porém, isso não significou nada: "Como laprimera, la segunda etapa de esta economia arranca de unhecho político y militar. La primera etapa nace de la Conquista. La segunda etapa se inicia con la Independencia"3 (MARIÁTEGUI, 2010, p. 35). As contradições entre os países da Europa e as disputas pelo mercado dos produtos da América influenciaram na independência e na formação dos Estados nacionais da América Latina. Para dar sequência ao processo de expropriação era necessário que a burguesia organizasse seus comitês, como bem atesta o Manifesto Comunista:

\footnotetext{
Cada uma dessas etapas de desenvolvimento da burguesia foi acompanhada por um progresso político correspondente. Segmentossociais oprimidos sob a dominação dos senhores feudais; organizado em associação armada autogerida na comuna; aqui república urbana independente, ali terceiro estado sujeito aos impostos na monarquia; ou, mais tarde, no período manufatureiro, contrapeso da nobreza na monarquia feudal ou absoluta; no geral, principal fundamento da grande monarquia - com o estabelecimento da grande indústria e do mercado mundial a burguesia conquistou, finalmente, o domínio político exclusivo no Estado representativo moderno. O poder do
}

\footnotetext{
${ }^{3}$ Como na primeira etapa, a segunda etapa dessa economia arranca um eixo político e militar. A primeira etapa nasce da conquista. A segunda etapa se inicia com a independência.
}

\begin{tabular}{|l|l|l|l|l|}
\hline Rovista Dialectus & Ano 5 & n.13 & Agosto - Dezembro 2018 & p. $78-99$ \\
\hline
\end{tabular}


Estado moderno não passa de um comitê que administra os negócios comuns da classe burguesa. (MARX, 2008, p. 11-12).

Pode-se considerar que a formação dos Estados nacionais e das repúblicas no continente americano tornou-se o momento da reorganização do capitale dos comitês de negócios. Embora a concepção burguesa negue esses fundamentos no sentido de vender a ideia segundo a qual o modelo republicano é a fiel representação do povo, tal concepção nega também a existência das classes sociais a fim de ocultar as contradições e os interesses antagônicos entre a burguesia e o proletariado. Nos dois lados desse antagonismo se expressam escancaradas contradições entre capital e trabalho. Quanto mais se trabalha, tanto mais se contribui para a concentração das riquezas de um lado e a miséria de outro. Pois bem: essas contradições se expressam nos grandes centros. $\mathrm{O}$ trabalho produziu prédios, indústrias, mas também produziu miseráveis em condições sub-humanas que enchem calçadas de pessoas indigentes nas cidades como São Paulo e Rio de Janeiro.

No capitalismo há pessoas passando fome, com armazéns e depósitos cheios de alimentos. Qual a solução proposta pela burguesia? Cadeias, pena de morte, esterilização de mulheres! A concentração de riqueza de um lado e aumento da população de outro causa pânico na burguesia. Embora tentando controlar o crescimento da população, reconhece Galeano que o capitalismo não previu essa pequena chateação e, por isso, sobra gente provocando riscos de rebeliões.

\footnotetext{
Faz-se o amor com entusiasmo e sem precauções. Cada vez mais fica gente a beira do caminho, sem trabalho no campo, onde o latifúndio reina com suas gigantescas terras ociosas, e sem trabalho na cidade, onde reinam as máquinas: o sistema vomita homens. As missões norte-americanas esterilizam maciçamente mulheres, semeiam pílulas, diafragmas, DIUs, preservativos e almanaques marcados, mas colhem crianças; obstinadamente, as crianças latino-americanas continuam nascendo, reivindicando seu direito natural de obter um lugar ao sol, nestas terras esplêndidas, que poderiam dar a todos o que a quase todos negam. (GALEANO, 1984, p. 16).
}

A história registra inúmeros massacres, assassinatos por parte dos representantes diretos do capital. Essa é a forma que eles encontram para enfrentar as contradições de classes e as disputas econômicas com que realmente produz a riqueza. Entre os mortos na América Latina é possível relembrar alguns nomes. Dentre os religiosos, cabe registrar: Camilo Torres 1929-1966, Colômbia; Padre Ezequiel Ramin 1953-1985, italiano missionário na Região de Cacoal,estado de Rondônia, Norte do Brasil; Jósimo Tavares, 1953-1987, nascido em Marabá, estado do Pará e que teve a

\begin{tabular}{|c|c|c|c|c|}
\hline Q Rovista Dialectus & Ano 5 & n. 13 & Agosto - Dezembro 2018 & p. $78-99$ \\
\hline
\end{tabular}


morte anunciada. Ele foi morto em 10 de maio de 1986 na região Bico do Papagaio, no estado do Pará. As mortes de religiosos, no entanto, continuam. Em 2007, pistoleiros assassinaram a irmã Dorothy Stang, no município de Anapu, no estado do Pará. O crime foi encomendado pelo fazendeiro Vitalmiro Bastos de Moura.

Agora, dentre os sindicalistas assassinados: no dia 22 de dezembro de 1988, Francisco Alves Mendes, o Chico Mendes, foi assassinado pelo fazendeiro Darly Alves da Silva e seu filho Darci Alves da Silva. O Chico Mendes era sindicalista, ambientalista e defendia o estudo científico em defesa da floresta amazônica, com objetivo de unificar a comunidade ribeirinha, os indígenas e os seringueiros, tudo sem devastar a floresta. O desejo de substituir tudo isso pela devastação da floresta e a criação de gado fez com que os fazendeiros dessem fim à vida de Chico Mendes. Em 1983, foi assassinada, em Alagoas, a sindicalista Margarida Alves. A lista dos crimes cometidos contra os que lutam por justiça é longa. A impunidade é indescritível. Voltando ao caso de Jósimo, em uma assembleia diocesana, praticamente 15 dias antes de sua morte, ficou registrada a seguinte situação em que o religioso se encontrava:

Em seu belíssimo Testamento Espiritual pronunciado durante a Assembleia Diocesana de Tocantinópolis, MA, no dia 27 de abril de 1986, poucos dias antes de seu assassinato, dizia Jósimo que sua morte estava anunciada, encomendada e prescrita nos anais das correntes que desejavam ardentemente eliminá-lo. Novos Anás e novos Caifás já o haviam julgado. Mas Jósimo se encontrava firme, pois havia assumido o seu trabalho pastoral no compromisso e na causa em favor dos pobres, dos oprimidos e injustiçados, impulsionado pela força do Evangelho. Jósimo declarou:

- Pois é, gente, eu quero que vocês entendam que o que vem acontecendo não é fruto de nenhuma ideologia ou facção teológica, nem por mim mesmo, ou seja, pela minha personalidade. Acredito que o porquê de tudo isso se resume em três pontos principais:

- Por Deus ter me chamado com o dom da vocação sacerdotal e eu ter correspondido - Pelo senhor bispo, D. Cornélio, ter me ordenado sacerdote- Pelo apoio do povo e do vigário de Xambioá, então Pe. João Caprioli, que me ajudaram a vencer nos estudos.

"O discípulo não é maior do que o Mestre. Se perseguirem a mim, hão de perseguir vocês também". Tenho que assumir. Agora estou empenhado na luta pela causa dos pobres lavradores indefesos, povo oprimido nas garras dos latifúndios. Se eu me calar, quem os defenderá? Quem lutará a seu favor? Eu, pelo menos, nada tenho a perder. Não tenho mulher, filhos e nem riqueza sequer, ninguém chorará por mim. Só tenho pena de uma pessoa: de minha mãe, que só tem a mim e mais ninguém por ela. Pobre. Viúva. Mas vocês ficam aí e cuidarão dela. Nem o medo me detém. É hora de assumir. Morro por uma justa causa. Agora quero que vocês entendam o seguinte: tudo isso que está acontecendo é uma conseqüência lógica resultante do meu trabalho na luta e defesa pelos pobres, em prol do Evangelho que me levou a assumir até as últimas conseqüências.A minha vida nada vale em vista da morte de tantos pais lavradores assassinados, violentados e despejados de suas terras. Deixando mulheres e filhos abandonados, sem carinho, sem pão e sem lar. É hora de se levantar e fazer a diferença! Morro por uma causa justa". Mas ele não imaginava que a morte viria tão cedo. Dia 10 de maio de 1986, dia das mamães, padre Jósimo foi assassinado covardemente enquanto subia as escadas do prédio da Mitra Diocesana de Imperatriz, MA, onde funcionava o escritório da CPTAraguaia-Tocantins. Ainda teve forças para entrar no

\begin{tabular}{|c|c|c|c|c|}
\hline Q Rovista Dialectus & Ano 5 & n.13 & Agosto - Dezembro 2018 & p. $78-99$ \\
\hline
\end{tabular}


hospital andando. Isso foi o que fazendeiros deram a dona Olinda, mãe do padre Jósimo, no dia das mães (Consulta on-line em 30/1/2018).

Houve também assassinatos de advogados trabalhistas. Enfim, são muitos, mas cabe destacar duas linhas de atuação que provocam a ira nos representantes do capital e seus capachos. A primeira está relacionada à luta direta pelas condições de vida, pela justiça. É uma luta econômica, mas tem ligação direta com a luta política. A segunda é uma luta indireta, vinculada aos apoiadores, que, em grande parte, estavam ligados à teologia da libertação. Cabe destacar, nesta segunda linha de atuação que sofre perseguição, que a igreja, principalmente a igreja católica, sempre teve dois lados. O lado de apoio aos poderes constituídos e o lado dos povos massacrados pelos poderes constituídos e representantes do capital.

Ainda há outros fatores relacionados aos fundamentos teológicos que têm implicações internacionais relacionadas com a conjuntura interna do clero, que influencia diretamente no comportamento do baixo clero nas suas relações com a população sofrida. Dependendo das circunstâncias, o baixo clero está do lado do povo, ou inteiramente contra. Quem fica contra o povo, normalmente são padres e bispos que tiram proveito da situação e se camuflam atrás de um púlpito para se apresentar como porta-voz da divindade, como expressão da verdade universal. Como disse certo padre, em 1992, numa assembleia do MST, sobre esse assunto. "No evangelho tem teologia para todos os gostos", para explorar ou para libertar.

\section{Efeitos dos preconceitos}

Conhecer objetos físicos, que ocupam espaços, pesos e medidas,é diferente da busca do conhecimento para estabelecer relações sociais de acordo com os princípios da justiça. Ora, a justiça é um conceito que se apresenta de acordo com o interesse da classe. Não é um conceito individual. A cultura burguesa estabelece, como principio para orientar a justiça, o conceito do ter e não ter. Trata-se de princípios da aquisição, mas essa aquisição está fundada no conceito da meritocracia. Assim, aquele que adquiriu por merecimento é justo; agora, quem não adquiriu por merecimento, é injusto. Como então se estabelecemtais princípios no conceito de superioridade entre negros brancose, mais no caso específico ainda do nazismo?

\begin{tabular}{|l|l|l|l|l|}
\hline Qevista Dialectus & Ano 5 & n.13 & Agosto - Dezembro 2018 & p.78-99 \\
\hline
\end{tabular}


Nas relações sociais, os conceitos e ospreconceitos são repassados de geração em geração, reproduzindo-se e se multiplicando entre pessoas que se entendem como superiores. Esse é um fenômeno manifesto nas escolas pelas crianças, pelos adolescentes e pelos jovens. De onde vem essa visão? Não é natural! Ela deriva do ensinamento de casa, das relações com pessoas que reafirmam a tese da superioridade.

Ademais, a concepção que reforça o conceito de superioridade traz consigo um ponto particular na percepção da noção de justiça. Por essa concepção, somente quem tem capacidade superior tem o poder de julgar. É assim,por exemplo, que se reforça a tese da isenção de um poder judiciário.Foi assim ainda na Inquisição, foi nas monarquias e continua nas repúblicas dos Estados nacionais. Com essa concepção, um ministro do supremo, ao apresentar o relatório de seu trabalho no conselho de um caso que não tinha provas materiais, mas tinha necessidade de condenar o investigado, por pressão política de setores do capital, se utiliza então da seguinte expressão: "Fizemos um trabalho primoroso, não é possível que alguém queira destruir". Aos olhos do público, o simples emprego dessa máxima basta para condenar o investigado. Mas, do ponto de vista rigoroso da teoria da justiça, caberia, portanto, a seguinte pergunta: "O que é um trabalho primoroso"?Somente essa afirmação não diz nada, porque tal trabalho, sem provas, se prestaria para atender a certos interesses econômicos. E foi o que aconteceu no Brasil a partir do ano de 2006.

\section{Aparência e essência}

Tudo o que aparece como fenômeno tem uma relação com a essência, mas o risco de formular conceitos por antecipação é quase inevitável em meio à consciência popular. Os princípios que orientam os juízos para conceituar alguém, p. ex., como "vagabundo", segundo o princípio da meritocracia, estruturam, por sua vez, os preconceitos na consciência daqueles que se orientam pela cultura burguesa. Ora, na concepção marxista, o trabalho é uma necessidade para a produção da existência humana; na concepção burguesa, o trabalho é um imperativo para a acumulação de riquezas.

O que não se explicita, por essa concepção, é que o trabalhador produz a riqueza para a burguesia, que são os representantes do capital. O nó do problema é que justo o trabalhador fica sem o produto do seu trabalho. Sim, o trabalho, na sociedade

\begin{tabular}{|l|l|l|l|l|}
\hline Q Rovista Dialectus & Ano 5 & n.13 & Agosto - Dezembro 2018 & p. 78-99 \\
\hline
\end{tabular}


burguesa, produz a riqueza, mas não para quem trabalha. Mais que isso: quem vive do trabalho, caso venhaa participar da organização do lado dos trabalhadores, é perseguido, massacrado, demitido pelos donos do capital. Por isso que quem organiza os trabalhadores contra a exploração corre risco de vida, como aconteceu com Chico Mendes, com Margarida Alves e com outros dirigentes sindicais.

Essas relações reforçam os princípios e osconceitos de superioridade, mas é uma superioridade mantida pela força. Foi o que Hitler fez em relação ao Holocausto. Trata-se de um conceito que permanece aindavivo na mente de muitos que ideologicamente prezam justo a teoria da superioridade. Com esses conceitos, o superior fica rico, o inferior vira delinquente; o superior está protegido pela lei, o inferior é marginal porque está à margem da lei. Essa é a realidade da América Latina.É assim, a título de exemplo, que a Revista URVIO, n 7 , publicada pelo FLACSO Equador, em 2009, pode ser considerada o retrato vivo da violência na América Latina.Essa revista está toda dedicada aos estudos da criminalidade no continente. Ela retrata um panorama geral de vários países, registrando o massacre sofrido pelos povos oprimidos. Ao mesmo tempo, há duas coisas nessa revista que merecem destaque. Trata-se doconceito de democracia e da organização das Forças Armadas. Através de inúmeras pesquisas fica evidente que os Estados nacionais, via as forças armadas, são, praticamente, patrocinadores dos grandes massacres a serviço do poder econômico.

En elsiglo XX, quienesanalizabamla violência em América Latina no teniandificuldades con entender a los atores principales. Estos actores se movían en lo conglomerado de organismos nebulosos relacionados con las Fuerzas Armadas, la seguridad del Estado y el sistema de contrainteligência, controlado por estamentos militares ${ }^{4}$ (KRUIJT, 2009, p. 40).

Sobre a democracia, diz a autora da pesquisa:

El orden democrático se sustenta en un orden econômico que está baseado en un desiquilíbrio, en una brecha profunda que tiene graves consecuencias para la estabilidade y para las possibilidad de desarrollo armónico de la region ${ }^{5}$ (p. 41).

\footnotetext{
${ }^{4}$ No século XX, quem analisava a violência na América Latina não tinha dificuldade para entender os atores principais. Estes atores se moviam em conglomerados de organismos nebulosos relacionados com as Forças Armadas, a segurança do Estado e um sistema de contrainteligência controlada por oficiais militares (Tradução de Sebastião Rodrigues Gonçalves).

${ }^{5}$ A ordem democrática se sustenta em um ordenamento econômico que está baseado num desiquilíbrio, isto é, em uma brecha profunda que tem graves consequências para a estabilidade e para as possibilidades de desenvolvimento econômico da região.
}

\begin{tabular}{|l|c|c|c|c|}
\hline Rovista Dialectus & Ano 5 & n.13 & Agosto - Dezembro 2018 & p. $78-99$ \\
\hline
\end{tabular}


Como escreve Galeano, segundo vimos, “[...] o desenvolvimento promove a desigualdade". Ora, essa máxima pôde ser constatada com a construção da Usina Hidroelétrica de Itaipu Binacional Brasil/Paraguai. A guerra do século XIX quase provocou o extermínio do Paraguai, deixando a população daquele país numa dependência quase que absoluta dos países vizinhos. Em função disso, com a construção da Usina de Itaipu, o Brasil passa a exercer a função de país subimperialista, vindo a controlar o país vizinho através da compra de energia. Tudo isso sem falar do massacre dos índios guaranis e dos agricultores que viviam às margens do Rio Paraná, tanto do lado brasileiro como do lado paraguaio. Um documento escrito por Paulo R. Schilling ${ }^{6}$ e Ricardo Canese $^{7}$ denunciava o tratado e reafirmando o papel de sub-imperialismo brasileiro, com um referencial do General Golbery do Couto e Silva. É o que sugere Paulo Schilling (1991, p. 32): [...] leiam o livro Geopolítica do Brasil, do General Golbery do Couto e
Silva, que, depois de traduzir Key country por "satélite privilegiado", defende
a tese de que devemos aceitar como inevitável a hegemonia dos EUA, mas
que essa deve ser exercida, na América do Sul, por intermédio do Brasil, o
"sócio menor" e, simultaneamente, o gendarme.

Tudo o que estava sendo construído era em nome do progresso. Esse progresso trouxe, p. ex., para a cidade de Foz do Iguaçu, a miséria junto com a riqueza. No pico da construção, entre 1978-1982, havia 40 mil operários trabalhando, enquanto o município de Foz do Iguaçupossuía 35 mil habitantes. Esse quadro mostra que inúmeros operários que trabalhavam na obra e residiam no próprio canteiro de obras não eram contabilizados como habitantes, já que outros vinham de cidades vizinhas distantes de até $100 \mathrm{~km}$ da obra. Quando encerrou a construção, inúmeros trabalhadores que vieram de várias regiões do Brasil ficaram sem emprego, mas continuaram morando na cidade, dos quais, muitos foram para o contrabando, outros para o tráfico, outros foram aventurar a sorte em outras regiões do Brasil.

A esse ponto, qual o cenário que se apresenta hoje para a América Latina? Tudo é incerto do ponto de vista da perspectiva para o povo, mas tudo é certo se levar em consideração como que o capital está organizado em nível mundial. É certo que a América Latina continua sendo um território de disputa pelas suas riquezas naturais, por tudo, inclusive, o que existe na região amazônica como cobiça do grande capital. Se

\footnotetext{
${ }_{7}^{6}$ Jornalista brasileiro exilado no Uruguai.

${ }^{7}$ Jornalista paraguaio exilado no Uruguai.
}

\begin{tabular}{|l|c|c|c|c|}
\hline Ronista Cialectus & Ano 5 & n.13 & Agosto - Dezembro 2018 & p. $78-99$ \\
\hline
\end{tabular}


antes havia um poder imperial, atualmente existe uma disputa interimperialistatentando disputar as riquezas. Nesse sentido, a democracia como regime político constitui-se num conceito vago, conforme análise de Rui Mauro Marini (2008, p. 22):

Desde o ponto de vista da reconstrução democrática, a burguesia põe a ênfase principal no fortalecimento do parlamento, onde pode com facilidade obter maioria, diretamente ou pela mediação da elite política a seu serviço.

\section{Conclusão}

Para concluir, note-se que o principal conceito que causa nebulosidade para compreender as relações sociais e a defesa da libertação e emancipação humanas está relacionado com a teoria política das ditaduras. O que entra em jogo sãoconceitostais como os de ditadura militar, ditadura civil, ditadura econômica, e, por último, no Brasil, o conceito de ditadura do Judiciário. Todas essas formas de organização poderiam ser resumidas num único conceito: o conceito de ditadura do capital sobre o trabalho. Esse quadro apenas evidencia, p. ex., a possibilidade real de militares assumires, autoritariamente, algum poder neste ou naquele país. Ora, sempre que isso ocorre, eles estão a serviço do capital. Quando o parlamento assume as diretrizes políticas, sempre tem como fim último o mercado e o capital. Essa é a lógica que impera em todas as circunstâncias.

O fato fundamental é que oJudiciário brasileiro, desde o Império,sempre esteve a serviço de algum poder, seja do imperador, seja militar ou parlamentar. Nesse sentido, a concepção de República e Democracia, com três poderes independentes, não passa de uma forma de uma simulação. $O$ fato mesmo é que essa tríplice forma de poder, se aceitarmos a concepção materialista-histórica de Marx e Engels, aplicada por Lênin, na Rússia Soviética, e por Mao Tse-tung,na China, mostra um dado importante: desde a era moderna, quando o capital se transformou no gigante universal, tendo a burguesia como a classe que opera os poderes, infundiu, com ele, também certa concepção de homem, de mulher, enfim, de seres humanos a ser seguido. Aquele que não adere a esse consagrado modelo está, de antemão, condenado a viver à margem da sociedade. Este é o verdadeiro conceito de inclusão social, política e econômica.

\section{REFERÊNCIAS}

\begin{tabular}{|c|c|c|c|c|}
\hline Qonista Dialectus & Ano 5 & n.13 & Agosto - Dezembro 2018 & p. $78-99$ \\
\hline
\end{tabular}


BITHENCOURT, Francisco. História das inquisições: Portugal, Espanha e Itália, século XV a XIX. São Paulo: Companhia das Letras, 2000.

CARNEIRO, Paulo Luiz. "Missionária Dorothy Stang é assassinada no Pará por defender grupos extrativistas". In: Jornal PAÍS, 10/05/17. Disponível em: $<$ http://acervo.oglobo.globo.com/em-destaque/missionaria-dorothy-stang-assassinadano-para-por-defender-grupos-extrati vistas-21321154>. Acesso em: 30 jan. 2018.

GALEANO, Eduardo. As veias abertas da América Latina.Tradução de Galena de Freitas. 19. ed. Rio de Janeiro: Paz e Terra, 1984.

KRUIJT, Dirk. La evolución histórica de actores de violência enla América Latina.Revista Urvio, Quito, n. 7, maio/2009, p. 38-49.

LENIN, V. I. Imperialismo: estágio superior do capitalismo. São Paulo: Expressão Popular, 2012.

MARINI, R. Mauro. A luta pela democracia. Revista Pensamento Crítico LatinoAmericano. São Paulo: CACSO/Expressão Popular, 2008.

MARX, Karl. Ideologia alemã. São Paulo: Boitempo, 2007.

Manifesto comunista. São Paulo: Expressão Popular, 2008.

PLATÃO. A república. Tradução Pietro Nasseti. São Paulo: Martin Claret, 2002.

SCHILLING, P.R. O homem, a ecologia, a soberania e o desenvolvimento. In: Itaipu geopolítica e corrupção. Dívida externa.São Paulo: Publicação CEDI - Centro Ecumênico de Documentação e Informação, 1991. Disponível em: $<$ https://educacao.uol.com.br/biografias/antonio-vieira.htm?cmpid=copiaecola $>$. Acesso em: 18 jan. 2018; < <http://www.ihu.unisinos.br/noticias/519890-padre-josimo-tavares27-anos-de-marti rio>. Acesso em: 30 jan. 2018.

MARIAREGUI, José Carlos. La tarea americana. Buenos Aires: Prometeo Libros: Consejo Latinoamericano de Ciencias Sociales - CLACSO, 2010. Disponível em: $<\mathrm{ttp}$ ://biblioteca.clacso.edu.ar/clacso/coediciones/20120611115450/Mariategui.pdf >. Acesso em: 30 jan. 2018.

VVAA. Documentário "Ezequiel Ramin - O Mártir da Opção pelos Pobres". São Paulo: Verbo Filmes, 2015. Disponível em: <http://www.a12.com/redacaoa12/ igreja/documentario-recorda-30-anos-da-morte-do-padre-ezequiel-ramim $>$. Acesso em:30 jan. 2018.

VVAA. “Assassinato de Margarida Maria Alves completa 30 anos na Paraíba”. In: G1 Paraíba, 11/08/2013. Disponível em: <http://g1.globo.com/pb/paraiba/noti cia/2013/08/assassinato-de-margarida-maria-alves-completa-30-anos-na-pb.html>.

Acesso em: 31 jan. 2018.

\begin{tabular}{|c|c|c|c|c|}
\hline Qovista Dialectus & Ano 5 & n.13 & Agosto - Dezembro 2018 & p. $78-99$ \\
\hline
\end{tabular}

